\begin{tabular}{l|l|l|}
\cline { 3 - 3 } CRITICAL & $\begin{array}{l}\text { Western Ghats } \\
\text { PARTERSHIP FUND }\end{array}$ & Special Series \\
\cline { 3 - 4 }
\end{tabular}

\title{
Reproductive biology of Puntius denisonii, an endemic and threatened aquarium fish of the Western Ghats and its implications for conservation
}

\author{
Simmy Solomon ${ }^{1}$, M.R. Ramprasanth ${ }^{2}$, Fibin Baby ${ }^{3}$, Benno Pereira ${ }^{4}$, Josin Tharian ${ }^{5}$, Anvar Ali ${ }^{6} \&$ \\ Rajeev Raghavan ${ }^{7}$ \\ 1,2,3,4,5,6,7 Conservation Research Group (CRG), St. Albert's College, Kochi, Kerala 682018, India \\ ${ }^{2}$ Integrated Rural Technology Center (IRTC), Mundur, Palakkad, Kerala, India \\ ${ }^{5}$ Department of Zoology and Environmental Science, St. John's College, Anchal, Kerala 691306, India \\ ${ }^{7}$ Durrell Institute of Conservation and Ecology, School of Anthropology and Conservation, University of Kent, Canterbury, Kent, CT2 \\ 7NZ, United Kingdom \\ Email: ${ }^{1}$ mariyasimmy@gmail.com, ${ }^{2}$ ramprasanthmanasam@gmail.com, ${ }^{3}$ fibinaqua@gmail.com, ${ }^{4}$ bennopereira@gmail.com, \\ 5 josinc@stjohns.ac.in, ${ }^{6}$ anvaraliif@gmail.com, ${ }^{7}$ rajeevraq@hotmail.com (corresponding author)
}

Date of publication (online): 26 September 2011 Date of publication (print): 26 September 2011 ISSN 0974-7907 (online) | 0974-7893 (print)

Editor: Neelesh Dahanukar

\section{Manuscript details:}

Ms \# 02608

Received 20 October 2010

Final received 13 September 2011

Finally accepted 15 September 2011

Citation: Solomon, S., M.R. Ramprasanth, F. Baby, B. Pereira, J. Tharian, A. Ali \& R. Raghavan (2011). Reproductive biology of Puntius denisonii, an endemic and threatened aquarium fish of the Western Ghats and its implications for conservation. Journal of Threatened Taxa 3(9): 2071-2077.

Copyright: (c) Simmy Solomon, M.R. Ramprasanth, Fibin Baby, Benno Pereira, Josin Tharian, Anvar Ali \& Rajeev Raghavan 2011. Creative Commons Attribution 3.0 Unported License. JoTT allows unrestricted use of this article in any medium for non-profit purposes, reproduction and distribution by providing adequate credit to the authors and the source of publication.

Author Detail, Author Contribution and Acknowledgements see end of this article.

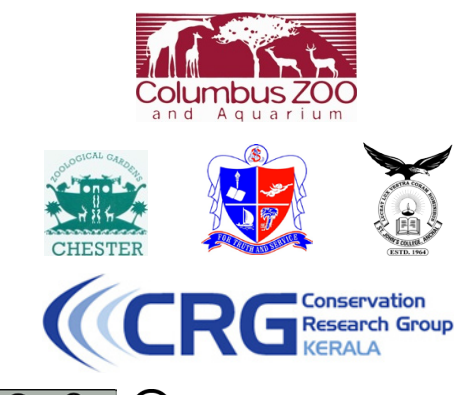

(c) (7) (口)

OPEN ACCESS | FREE DOWNLOAD
Abstract: This study presents fundamental information on the reproductive biology of Puntius denisonii, an endemic and threatened aquarium fish of the Western Ghats Hotspot. Results are based on the observations from three river systems, Chandragiri, Valapattannam and Chaliyar. Maximum observed total length in $P$. denisonii was $162 \mathrm{~mm}$ and $132 \mathrm{~mm}$ for males and females, respectively. Males attained sexual maturity at a lower size than females with mean size at first maturity determined as $85.33 \pm 1.52 \mathrm{~mm}$ for males and $95.66 \pm 1.15 \mathrm{~mm}$ for females. Puntius denisonii spawned from October to March with minor differences in the peak breeding months between the three river systems, which were studied. Sex ratio deviated significantly from 1:1 and was skewed in favour of males. Absolute fecundity varied from 376 (fish of $102 \mathrm{~mm}$ total length) to 1098 (fish of $106 \mathrm{~mm}$ total length) eggs. Currently, the closed seasons for $P$. denisonii have been put in place during June, July and October based on the (mis)assumption that the species breeds during these three months. However, the results of the present study have helped us to understand more about the reproductive biology of the species so as to recommend more appropriate seasonal closures. The months from October until March need to be designated as a closed season for protecting the breeding population of $P$. denisonii.

Keywords: Conservation, endemic fish, Puntius denisonii, reproduction, threatened, Western Ghats.

\section{INTRODUCTION}

Unsustainable collection of endemic freshwater fish for the aquarium trade is an emerging conservation issue in the tropics, which has resulted in the population decline of several species such as the Asian Arowana Scleropages formosus (Rowley et al. 2009), Silver Arowana Osteoglossum bicirrhosum (Moreau \& Coomes 2006), Celestial Pearl Danio Danio margaritatus (Roberts 2007) and Bala Shark Balantiocheilos

This article forms part of a special series on the Western Ghats of India, disseminating the results of work supported by the Critical Ecosystem Partnership Fund (CEPF), a joint initiative of l'Agence Française de Développement, Conservation International, the Global Environment Facility, the Government of Japan, the MacArthur Foundation and the World Bank. A fundamental goal of CEPF is to ensure civil society is engaged in biodiversity conservation. Implementation of the CEPF investment program in the Western Ghats is led and coordinated by the Ashoka Trust for Research in Ecology and the Environment (ATREE). 
melanopterus (Ng \& Tan 1997). Nevertheless, wild caught aquarium fish industry receives little attention from ichthyologists, local governments and conservation organizations throughout the world, with very little research, and no legislative controls (Moreau \& Coomes 2007; Rowley et al. 2009).

The Western Ghats (WG), an exceptional Hotspot of freshwater fish diversity and endemism in peninsular India (Kottelat \& Whitten 1996; Dahanukar et al. 2004) is an important region for aquarium fish collections (Tlusty et al. 2008). More than a hundred species including several threatened endemics are currently collected and exported from this region (Raghavan 2010). Similar to other parts of the world, aquarium fish collections in WG are open access and unregulated, raising concerns about their ecobiological impact (Raghavan 2010). Several endemic species are known to be facing serious population decline due to indiscriminate collections for the trade (Kurup et al. 2004; Raghavan et al. 2009).

One such endemic species, which is currently considered to be under severe threat from the aquarium pet trade is the Denison Barb (AKA Red Lined Torpedo Barb and Miss Kerala), Puntius denisonii, a small- to medium- sized cyprinid having an extremely restricted distribution in the southern WG (Prasad et al. 2008). Due to its limited distributional range in the southern WG and declining populations, $P$. denisonii was assigned Vulnerable species status in the IUCN Red List (Devi \& Boguskaya 2009). The recently completed IUCN Freshwater Biodiversity Assessments in the WG has categorised this species as Endangered (Ali et al. 2010). Nevertheless, this species is poorly known with no information on its micro level distribution, life history, ecology and demography (Raghavan et al. 2010). The objective of this study was to understand the reproductive biology of $P$. denisonii, and discuss its implications on the conservation of wild populations.

\section{MATERIALS AND METHODS}

Samples for the present study were purchased from aquarium fish collectors operating in three major rivers of the southern WG, viz., Chandragiri, Valapattannam and Chaliyar (Fig. 1) between December 2008 and November 2009. Fish were received live in packed polythene bags and euthanized immediately by immersing in ice-slurry. Subsequently they were preserved in $4 \%$ formaldehyde and transferred to the laboratory, where each individual was tagged, measured (Total Length $T_{L}$ ), weighed (Total Weight $\mathrm{T}_{\mathrm{w}}$ ) and sexed (by internal sexual characteristics or by examining gonads under a dissecting microscope). Gonads were subsequently removed, weighed $\left(\mathrm{G}_{\mathrm{w}}\right)$ and preserved in $4 \%$ formaldehyde, while matured ovaries with visible eggs were preserved in Gilson fluid $(100 \mathrm{ml} 60 \%$ alcohol, $800 \mathrm{ml}$ water, $15 \mathrm{ml} 80 \%$ nitric acid, $18 \mathrm{ml}$ glacial acetic acid, $20 \mathrm{~g}$ mercuric chloride) to break down ovarian tissues.

Gonado somatic index (GSI) was calculated as 100 $X \mathrm{G}_{\mathrm{w}}\left(\mathrm{T}_{\mathrm{w}}-\mathrm{G}_{\mathrm{w}}\right)^{-1}$ and used to delineate the spawning season. The length at which $50 \%$ of male and female fish were in maturing stages III and IV was taken as the minimum length at first maturity (Bagenal 1978). Deviation from the expected 1:1 sex ratio was analyzed using chi-square test (Corder \& Foreman 2009). Absolute fecundity $\left(A_{F}\right)$ was estimated by weighing all the eggs in the ovary and also by counting three sub samples of eggs from different parts of the ovary. Relative fecundity $\left(\mathrm{R}_{\mathrm{F}}\right)$ was calculated as $\mathrm{T}_{\mathrm{F}} /$ $T_{W}$. Relationship of $A_{F}$ with both $T_{L}$ and $T_{W}$ were determined by plotting the points on a log-log scale as these are expected to be allometric relationships described by a general power function $\mathrm{y}=\mathrm{ax}{ }^{\mathrm{b}}$, where $\mathrm{y}$ is the dependent variable, $\mathrm{x}$ is independent variable, $\mathrm{b}$ is the scaling exponent and $\mathrm{a}$ is the normalization constant (Kharat et al. 2008). A least square line was fitted to the scatter of the data and the significance of the relationship was determined from coefficient of determination $\left(\mathrm{R}^{2}\right)$ and uncertainty in the prediction of the exponent by calculating its standard error.

\section{RESULTS}

Of 1,080 fish analysed, 792 (73.33\%) were mature, composed of 570 males $(52.77 \%)$ and 222 females (20.55\%). Sex ratio of $P$. denisonii from all three rivers deviated significantly from the expected 1:1 and was extremely skewed in favour of males (Table 1). GSI in all three river systems peaked during October to March with minor differences between rivers (Fig. 2). Peak maturity of $P$. denisonii in Chandragiri and Valapattannam rivers were observed during December 


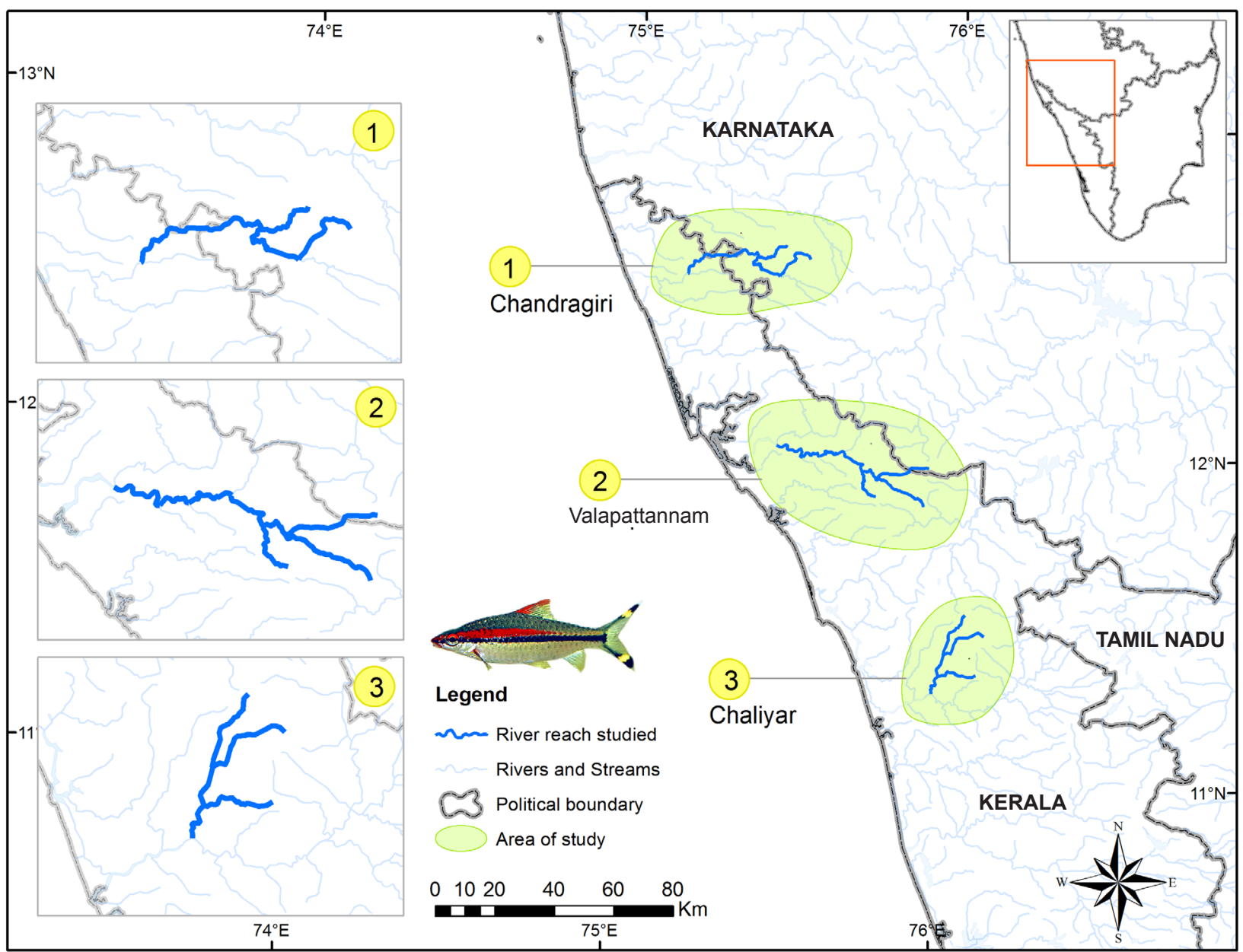

Figure 1. The three river systems from where $P$. denisonii were collected in southern India

and, in the Chaliyar River during February. No temporal variation in spawning season could be observed even though the three rivers from where the fish samples originated were located at different latitudes (Fig. 1).

In $P$. denisonii, males start to mature earlier than females (Table 1). Mean sizes at first maturity was $85.33 \pm 1.52 \mathrm{~mm}_{\mathrm{L}}$ (male) and $95.66 \pm 1.15 \mathrm{~mm} \mathrm{~T}_{\mathrm{L}}$ (females). Absolute fecundity $\left(\mathrm{A}_{\mathrm{F}}\right)$ in $P$. denisonii from the Chandragiri River system varied from 376 $\left(102 \mathrm{~mm} \mathrm{~T}_{\mathrm{L}}\right)$ to $1098\left(106 \mathrm{~mm}_{\mathrm{L}}\right)$ with a mean of $762.66 \pm 264.270$ eggs/fish $(n=12)$, while relative fecundity $\left(\mathrm{R}_{\mathrm{F}}\right)$ was between 36.11 and 94.65 with a mean of $70.44 \pm 22.79$ eggs. Although we obtained several fecund female specimens of $P$. denisonii from the other two rivers as well, they were released back into the stream without sacrificing for our study. This was done taking into consideration the threatened status of the species, and based on our assumption that the same

Table 1. Maximum observed length, minimum size at first maturity and sex ratio of Puntius denisonii from three river systems of Western Ghats

\begin{tabular}{|l|c|c|c|c|c|c|}
\hline River & \multicolumn{2}{|c|}{ Max length $\left(\mathrm{mm} \mathrm{T}_{\mathrm{L}}\right)$} & Min size at maturity $\left(\mathrm{mm} \mathrm{T}_{\mathrm{L}}\right)$ & \multicolumn{2}{c|}{ Sex ratio $(\mathrm{M}: \mathrm{F})$} \\
\hline & Male & Female & Male & Female & Ratio & Chi Square $\left(\chi^{2}\right)$ \\
\hline Chaliyar & 110 & 100 & 84 & 97 & $1: 0.35$ & $63.947^{*}$ \\
\hline Chandragiri & 162 & 132 & 87 & 95 & $1: 0.36$ & $49.717^{*}$ \\
\hline Valapattannam & 136 & 105 & 85 & 95 & $1: 0.57$ & $19.810^{*}$ \\
\hline
\end{tabular}

${ }^{*}-\mathrm{P}<0.0001$ 


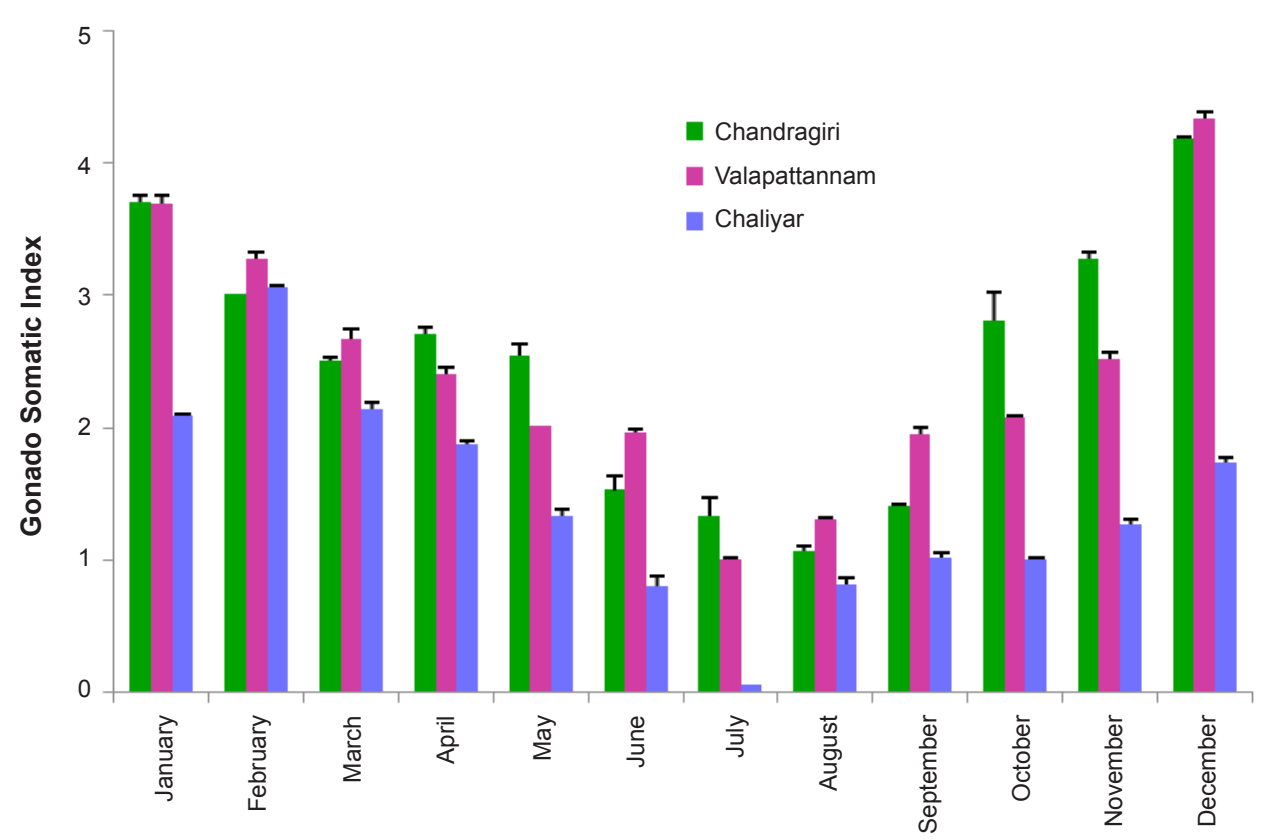

Figure 2. Annual changes in the mean Gonado Somatic Index (GSI) of Puntius denisonii from three river systems of Western Ghats (error bars denote standard deviation).

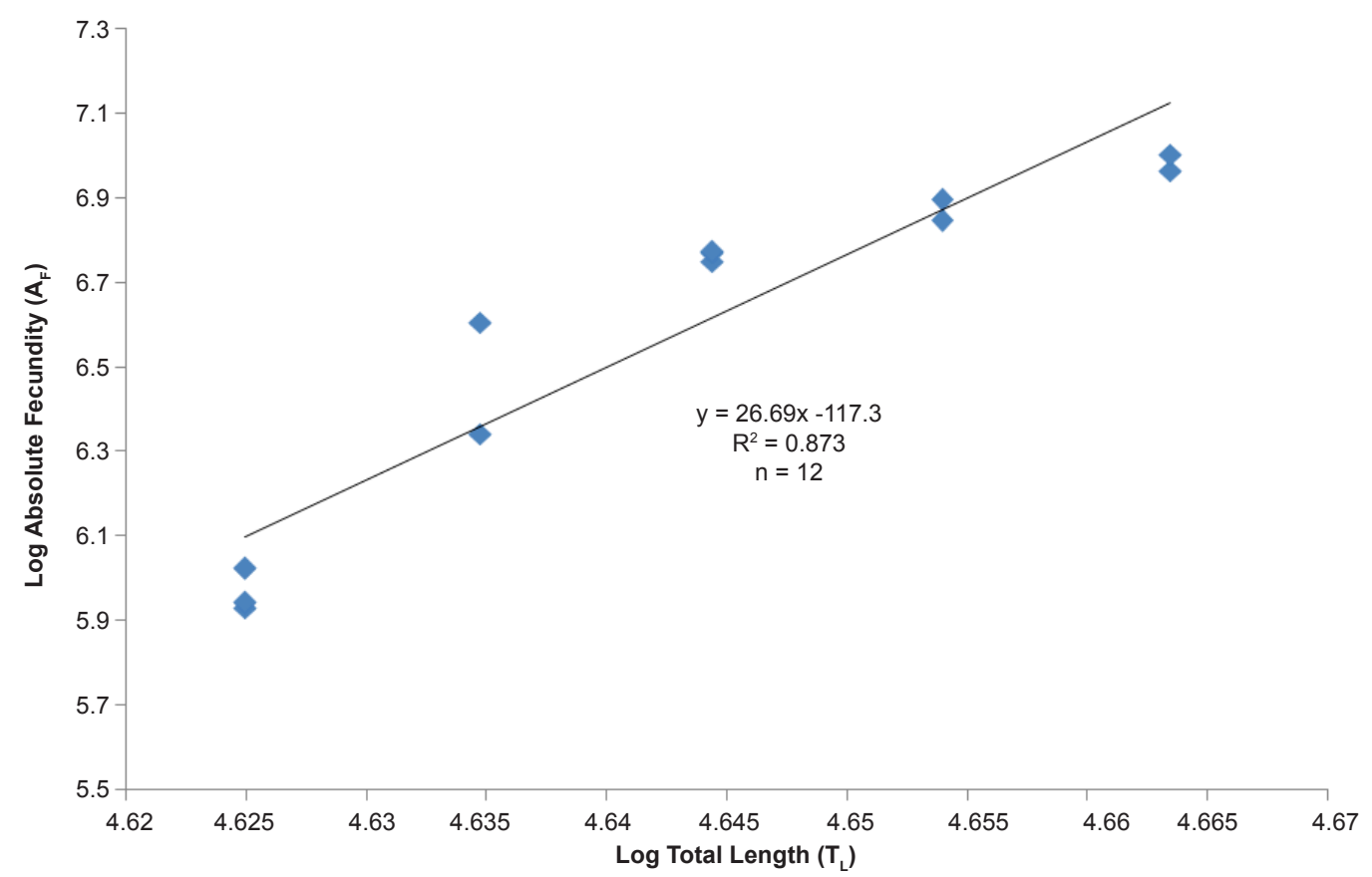

Figure 3. Relationship between Total Length and Absolute Fecundity in Puntius denisonii from Chandragiri River

species may show similar range of fecundity between river systems. The relationship of absolute fecundity with total length was best explained as $\log \mathrm{A}_{\mathrm{F}}=26.69$ $\log \mathrm{T}_{\mathrm{L}}-117.3$ (Fig. 3) and the relationship of absolute fecundity with total weight was better explained as $\log \mathrm{A}_{\mathrm{F}}=9.55 \log \mathrm{T}_{\mathrm{W}}-16.10$ (Fig. 4).

\section{DISCUSSION}

Although sex ratio of a fish may deviate from the normal 1:1 due to a number of factors (Nikolsky 1963; Alp et al. 2003) extremely skewed ratios such as those observed in the present study are very rarely 


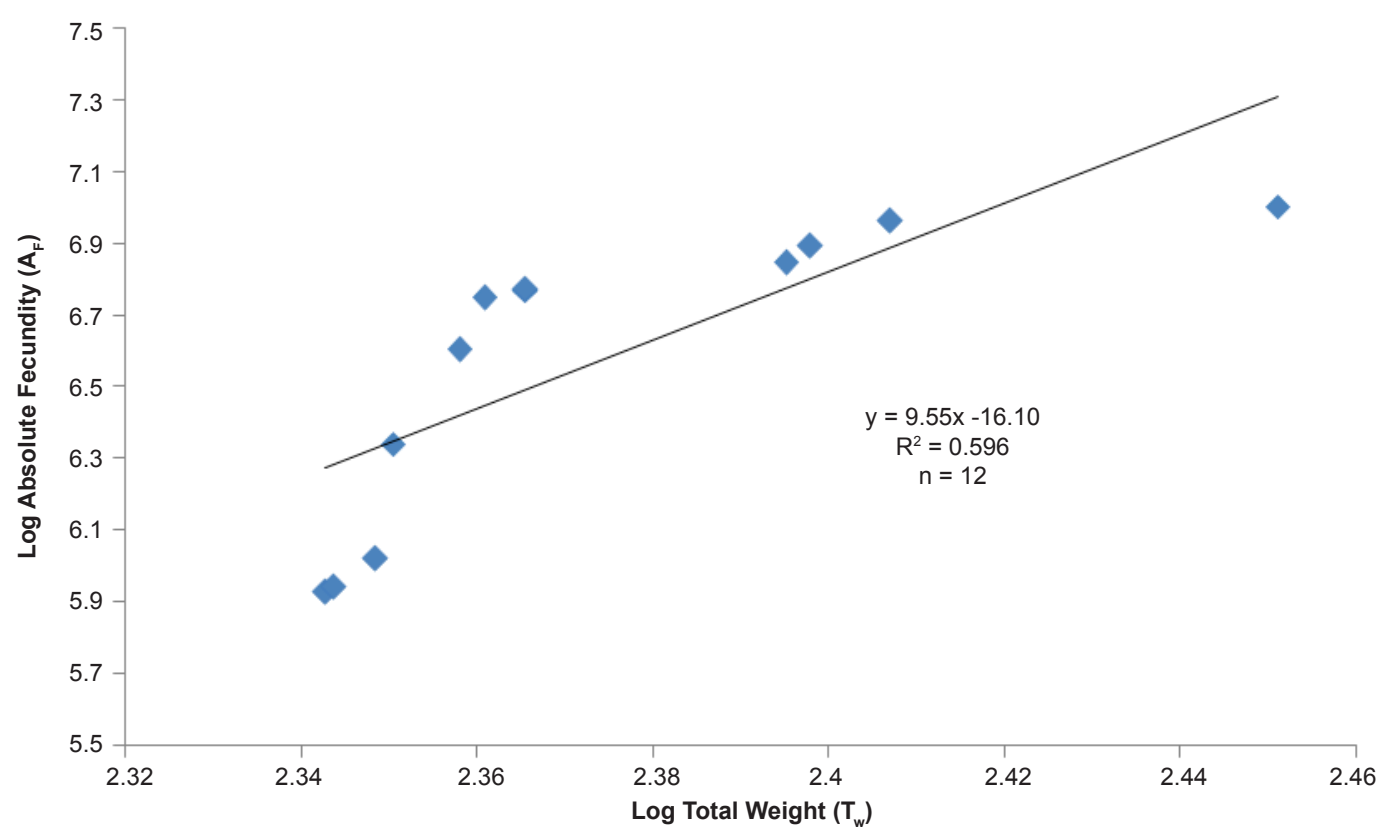

Figure 4. Relationship between Total Weight and Absolute Fecundity in Puntius denisonii from Chandragiri River

encountered. One possible reason for this skew in $P$. denisonii could be the differential habitat occupation of the sexes. i.e., females preferring deeper waters and therefore being less vulnerable to capture and males on the other hand living in shallow areas from where they are easily caught. Such differential habitat occupancy by sexes has been earlier observed in tropical fish (Macuiane et al. 2009; Lewis et al. 2005). Skewed ratios may also occur as a result of the differences in instantaneous natural mortality between sexes (Vincentini \& Araujo 2003). However, there is no information on the demography of $P$. denisonii to support such an argument.

Results obtained in this study on the spawning season are contrary to the information in gray literature. $P$. denisonii was reported to spawn during June-August with mature specimens observed from May (Radhakrishnan \& Kurup 2005). However, the annual dynamics of GSI from three river systems of WG observed in this study indicated that $P$. denisonii breeds during October to March.

As the first step towards conservation, the State Department of Fisheries in Kerala (India) has issued an order, restricting collection and exports of $P$. denisonii from the rivers of the region (Clarke et al. 2009). Several management measures including quotas, restrictions on gears, catch size, and a seasonal closure of fishery have been enforced (Mittal et al.
2009). Currently, the closed seasons for $P$. denisonii have been put in place during June, July and October (Clarke et al. 2009) based on the assumption that the species breeds during these three months. However, results of the present study provide hard evidence that this seasonal closure is mistimed and has been designed without proper understanding of the biology of this species.

Absolute fecundity of $P$. denisonii is extremely low when compared to other cyprinids such as $P$. sarana (Chandrasoma \& de Silva 1981) and Rasbora daniconius (Nagendran et al. 1981). However, three endemic cyprinids threatened by aquarium collections in Sri Lanka, $P$. nigrofasciatus, $P$. cumingi and $P$. pleurotaenia are known to have a low absolute fecundity (151-638 for 46-64 $\mathrm{mm} \mathrm{T}_{\mathrm{L}}$ ) (de Silva \& Kortmulder 1976; Chandrasoma et al. 1994) similar to $P$. denisonii.

As the scale of the body increases the relationship depicting change in lengths and weights of different body parts change as allometric relationships. As per Euclidian geometry, the lengths of two tissues should show an exponent of one and the relationship depicting change in length versus weight should show an exponent of $1 / 3$ depicting isometric relationships. Kharat et al. (2008, p. 13) suggested that if the volume of each egg is constant, then the fecundity should scale as unity with the ovary volume and as a result, 
at a constant density, the fecundity should change as a cube of length of the fish and as unity with weight of the fish under isometry. On the contrary, in our analysis the fecundity changed as $27^{\text {th }}$ power of length and $10^{\text {th }}$ power of the weight of the fish. Our results show that the scaling exponent of the relationship of absolute fecundity with both total length and total weight in $P$. denisonii were significantly different from the values suggested by Euclidian geometry and thus the fecundity grows non-isometrically. As a result, the larger fish (length and weight) have drastically more fecundity then the slightly smaller individuals. Thus, larger specimens contribute more to reproduction in the species and the removal of larger individuals from a population will have a drastic impact on the demographics and subsequently on the status.

The peculiar characters of reproduction including an extremely low absolute fecundity and a skewed sex ratio will undoubtedly hamper natural recruitment, influence population dynamics and lead to low population levels in P. denisonii. This cyprinid may therefore be unsuited for large scale collections for the pet trade. The present study has also revealed that closed seasons, the most important conservation plan for $P$. denisonii implemented by the local government in Kerala is wrongly timed, and has little or no impact on the protection of wild stocks. There is hence an urgent need for re-designing conservation strategies for the species based on biological information such as those generated in this study. The closed season for protecting the breeding population of $P$. denisonii in the rivers of northern Kerala should be put in place from October to March.

\section{REFERENCES}

Ali, A., R. Raghavan \& N. Dahanukar (2010). Puntius denisonii In: IUCN 2011. IUCN Red List of Threatened Species. Version 2011.1. <www.iucnredlist.org>. Downloaded on 19 August 2011.

Alp, A., C. Kara \& H.M. Buyukcapar (2003). Reproductive biology of brown trout, Salmo trutta macrostigma Dumeril 1858 , in a tributary of the Ceyhan River which flows into the eastern Mediterranean Sea. Journal of Applied Ichthyology 19: 346-351.

Bagenal, T.B. (1978). Aspects of fish fecundity, pp. 75-101. In: Gerking, S.D. (ed). Ecology of Freshwater Fish Production. Blackwell, London.
Chandrasoma, J. \& de Silva (1981). Reproductive biology of Puntius sarana, an indigenous species and Tilapia rendalli, an exotic, in an ancient man-made lake in Sri Lanka. Fisheries Management 12: 17-28.

Chandrasoma, J., H.C. Chin \& H.P. Amandakoon (1994). Reproductive biology and breeding of Cuming's Barb (Puntius cumingii Gunther). Journal of Applied Ichthyology 10(2-3): 209-214.

Clarke, M. (2009). Why ban won't protect Puntius denisonii. Practical Fish Keeping Magazine http://www. practicalfishkeeping.co.uk/pfk/pages/sitemap.php/show_ article.php?article_id=717 accessed $19^{\text {th }}$ June 2009.

Corder, G.W. \& D.I. Foreman (2009). Nonparametric Statistics for Non-Statisticians: A Step-by-Step Approach. Wiley, 247pp.

Dahanukar, N., R. Raut \& A. Bhat (2004). Distribution, endemism and threat status of freshwater fishes in the Western Ghats of India. Journal of Biogeoography 31: 123-136.

de Silva, S.S. \& K. Kortmulder (1976). Some aspects of the biology of three species of Puntius (=barbus) Pisces Cyprinidae, endemic to Sri Lanka. Netherlands Journal of Zoology 27(2): 182-194.

Devi, R. \& N. Boguskaya (2009). IUCN Red List of Threatened Species Version 2009.2; www.iucnredlist.org accessed on 8 November 2009.

Kharat, S.S., Y.K. Khillare \& N. Dahanukar (2008). Allometric scaling in growth and reproduction of a freshwater loach, Nemacheilus mooreh (Sykes 1839). Electronic Journal of Ichthyology 4(1): 8-17.

Kottelat, M. \& T. Whitten (1996). Freshwater biodiversity in Asia with special reference to fish. World Bank Technical Paper 343. Washington, USA.

Kurup, B.M., K.V. Radhakrishnan \& T.G. Manojkumar (2004). Biodiversity status of fishes inhabiting rivers of Kerala (S. India) with special reference to endemism, threats and conservation measures, pp. 163-182. In: Welcome, R.L. \& T. Petr (eds.). Proceedings of LARS2. 2nd Large Rivers Symposium. Mekong River Commission (MRC) and Food and Agricultural Organization (FAO).

Lewis, D.S. \& N.F. Fontoura (2005). Maturity and growth of Paralonchurus brasiliensis females in southern Brazil (Teleostei, Perciformes, Sciaenidae). Journal of Applied Ichthyology 21: 94-100.

Macuiane, M.A., E.K.W. Kaunda, D.M. Jamu \& G.Z. Kanyerere (2009). Reproductive biology and breeding of Barbus paludinosus and B. trimaculatus (Teleostei: Cyprinidae) in Lake Chilwa, Malawi: implications for fisheries management. African Journal of Aquatic Science 34(2): 123-130.

Mittal, R. (2009). Business unusual: Conserving Miss Kerala. Aquarama Magazine 12: 7-9.

Moreau, M.A. \& O.T. Coomes (2007). Aquarium fish exploitations in Western Amazonia: conservation issues in Peru. Environmental Conservation 34(1): 12-22.

Moreau, M.A. \& O.T. Coomes (2006). Potential threat of the 
international aquarium fish trade to silver arawana Osteoglossum bicirrhosum in the Peruvian Amazon. Oryx 40: 152-160.

Ng, P.K.L. \& H.H. Tan (1997). Freshwater fishes of Southeast Asia: potential for the aquarium fish trade and conservation issues. Aquarium Sciences and Conservation 1: 79-90.

Nagendran, R., K. Shakuntala, G.N. Natarajan \& H.R.K. Vasan (1981). Observations on the fecundity of the cyprinid Rasbora daniconius (Hamilton). Proceedings of the Indian Academy of Sciences (Animal Science) 90(4): 381388.

Nikolsky, G.W. (1963). The Ecology of Fishes. Academic Press, London.

Prasad, G., A.P.H. Ali \& R. Raghavan (2008). Threatened Fishes of the World: Puntius denisonii Day (Cyprinidae) Environmental Biology of Fishes 83(2): 189190.

Radhakrishnan, K.V. \& B.M. Kurup (2005). Aspects of life history traits of Puntius denisonii (Day), an endemic and threatened ornamental fish of Kerala. Sustain Fish 2005 International Symposium on Sustainability of Fish Production Systems and Appropriate Technologies for Utilization. Cochin University of Science and Technology, 16-18 March 2005. Kochi, India. Abstract SAQ E18

Raghavan, R. (2010). Ornamental fisheries and trade in Kerala, pp. 169-197. In: Sonnenschein, L. \& A. Benziger (eds.). Fish Conservation in Kerala. World Aquariums and Oceans Federation, St. Louis, USA.

Raghavan, R., G. Prasad, A.P.H. Ali, B. Pereira, F. Baby \& M. Ramprasanth (2010). Miss Kerala added to the IUCN Red List of threatened species. Current Science 98(2): 132.

Raghavan, R., G. Prasad, A.P.H. Ali, B. Pereira \& L. Sujarittanonta (2009). Damsel in distress - the tale of Miss Kerala, Puntius denisonii (Day) an endemic and endangered cyprinid of Western Ghats biodiversity hotspot, India Aquatic Conservation - Marine and Freshwater ecosystems 19(1): 67-74.

Raghavan, R., G. Prasad, A.P.H. Ali \& L. Sujarittanonta (2007). 'Boom and Bust Fishery' in a Biodiversity Hotspot - Is the Western Ghats (South India) losing its most celebrated ornamental fish, Puntius denisonii, Day? Current Science 92(12): 1671-1672.

Rowley, J.J.L., D.A. Emmet \& S. Voen (2008). Harvest, trade and conservation of the Asian Arowana, Scleropages formosus in Cambodia. Aquatic Conservation - Marine and Freshwater Ecosystems 18(7): 1255-1262.

Tlusty, M.F., S. Dowd \& R. Raghavan (2008). Saving forests through the fisheries: ornamental fisheries as a means to avoid deforestation. Ornamental Fish International Journal 56: 21-25.

Vincentini, R.N. \& F.G. Araujo (2003). Sex ratio and size structure of Micropogonias furnieri (Desmarest 1823) (Perciformes Sciaenidae) in Sepetiba Bay, Rio De Janeiro, Brazil. Brazilian Journal of Biology 63(4): 559-566.

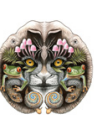

\section{Malayalam Abstract:

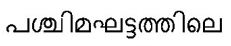

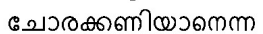

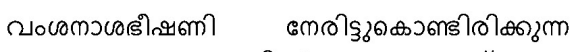

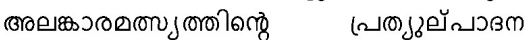

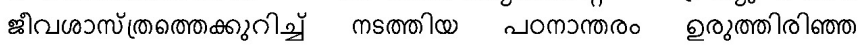

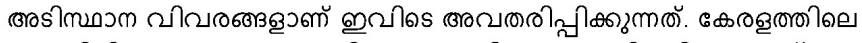

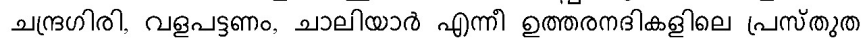

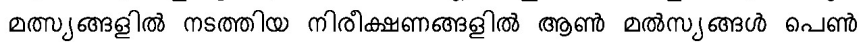

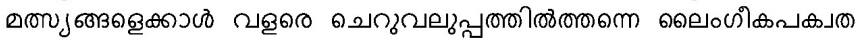

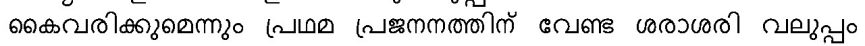

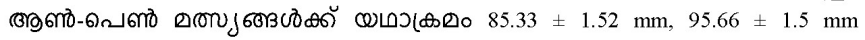

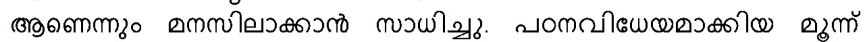

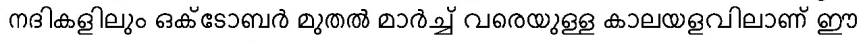

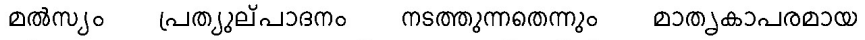

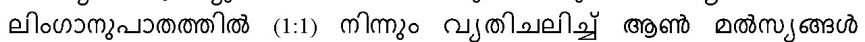

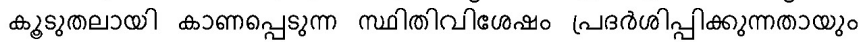

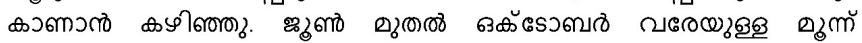

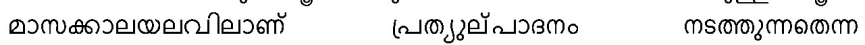

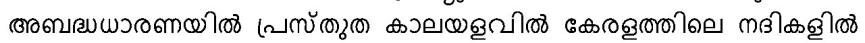

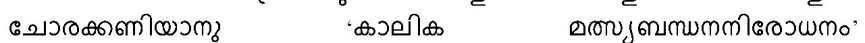
mS Зी

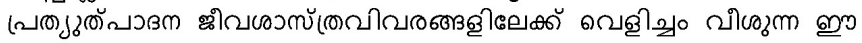

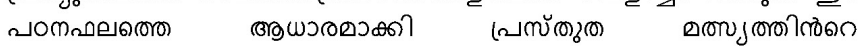

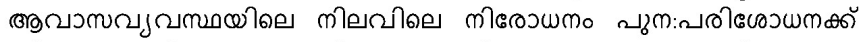

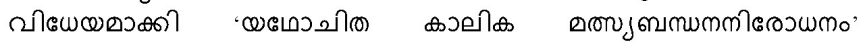

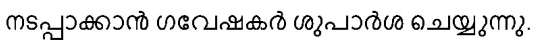

